\title{
A Comparative Perspective ON CONSTITUTIONAL COMPLAINT: DISCUSSING MODELS, PROCEDURES, AND DECISIONS
}

\author{
M. Lutfi Chakim* \\ Seoul National University, Korea \\ chakim@snu.ac.kr
}

\begin{abstract}
The constitutional complaint is one of the important constitutional court jurisdictions that can be described as a complaint or lawsuit filed by any person who deems his or her rights has been violating by act or omission of public authority. Currently, the constitutional court in many countries have adopted a constitutional complaint system in a variety of models. However, the first application of the constitutional complaint jurisdiction came from Europe. In Austria, the constitutional complaint is allowed against the administrative actions but not against the court decisions. While Germany and Spain have a similar model that is a complaint against an act of the public authority including court decisions. In Asia, it is imperative that the court in Asia actively participate in the Association of Asian Constitutional Courts and Equivalent Institutions (AACC). The AACC members have adopted a system of constitutional adjudication in a variety of models, and when it comes to jurisdictions, out of sixteen AACC members, there are four countries (Azerbaijan, South Korea, Thailand, and Turkey) have the constitutional complaint in their jurisdictions. In Azerbaijan, constitutional complaint is comparatively broad. Azerbaijan's Constitutional Court can handle constitutional complaint against the normative legal act of the legislative and executive, an act of a municipality and the decisions of courts. In contrast, even though constitutional complaint in South Korea and Thailand can be against the exercise and non-exercise of state power, constitutional complaint cannot be filed against court decisions. In Turkey, the constitutional complaint mechanism is coupled with the regional system of human rights protection. The Turkish Constitutional Court handles complaints from individuals concerning
\end{abstract}

* LL.M Candidate at the Seoul National University (SNU), South Korea, and Researcher at the Constitutional Court of Indonesia. 
violations of human rights and freedoms falling under the joint protection of the Turkish Constitution and the European Convention on Human Rights (ECHR). This paper argues that constitutional complaint represents the main part of the constitutional court, and through a comparative perspective among three countries in Europe and four AACC members are expected to provide lessons for the other AACC members that do not have a constitutional complaint mechanism, such as Indonesia.

Keywords: Comparative Law, Constitutional Complaint, Constitutional Court, Association of Asian Constitutional Courts and Equivalent Institutions.

\section{INTRODUCTION}

The protection of fundamental rights means that when a breach of the constitution occurs, the rights holder must be given legal remedies to maintain his or her rights, which are guaranteed by the constitution. In many countries, the protection of fundamental rights is a significant issue, the first point of note is that fundamental rights protection is complicated and continues to pose challenges.

The idea of constitutionalism and the guarantee of the protection of fundamental rights are one manifestation in modern democracies. This assurance has been supported by the establishment of various legal instruments in order to ensure the protection of the fundamental rights as a responsibility of the state. In this context, the constitutional complaint is one of the legal mechanisms designed to reinforce the guarantee of the protection of citizens' rights against any state action, in all branches of power that violates the rights of citizens.

According to Palguna, the history of constitutional complaints begins and is directly related to and even a logical consequence of the requirements of the constitutional state. In brief, the theoretical construction is explained as follows. The first characteristic of a modern constitutional state is constitutionalism, which means that state administration is based on and (therefore) may not contradict with the constitution. Thus, the constitution must be actually applied or complied with in practice, instead of merely playing an aspirational role. 
In order to secure strict compliance and performance of the constitution in practice, the idea to establish a constitutional court emerges. ${ }^{1}$

The term "constitutional complaint" applied in this paper refers to an individual citizen claiming that one of his or her constitutional rights has been violated by an act or omission of the public authority. Gerhard Dannemann characterized constitutional complaint by four factors. First, they provide a judicial remedy against violations of constitutional rights; second, they lead to separate proceedings which are concerned only with the constitutionality of the act in question and not with any other legal issues connected with the same case; third, they can be lodged by the person adversely affected by the act in question; and, fourth, the court which decides the constitutional complaint has the power to restore to the victim his or her rights. ${ }^{2}$

Currently, the constitutional court in many countries have adopted a constitutional complaint system in a variety of structures and models. ${ }^{3}$ However, the first application of the constitutional complaint jurisdiction came from Europe. Austria, with Hans Kelsen playing a major role, established the first constitutional court as we understand constitutional courts today. The Austrian Constitutional Court (Verfassungsgerichtshoft) has the authority to decide complaints against laws, regulations, international treaties, and against administrative actions, but there is no constitutional complaint against acts of the judiciary. ${ }^{4}$ In Germany, as one of the most advanced mechanisms among countries in dealing with this issue, the Federal Constitutional Court of Germany (Bundesverfassungsgericht) has the authority to handle constitutional complaint cases related to an act of a public authority. This therefore includes complaints concerning the constitutionality of a law, an administrative act, and even a court decision. ${ }^{5}$ Another interesting model of the protection of fundamental

\footnotetext{
I Dewa Gede Palguna, "Constitutional Complaint and the Protection of Citizens the Constitutional Rights," Constitutional Review 3, no. 1 (May 2017): 2-3.

Gerhard Dannemann, "Constitutional Complaints: The European Perspective," the International and Comparative Law Quarterly 43, no. 1 (January 1994): 142.

Explanation on the model of constitutional complaint is discussed in Chapter II and III of this paper.

4 Austria Constitution, Art. 139, Art. 140 and Art. 144.

5 The authority of the German Constitutional Court to decide constitutional complaint cases is described in Article 93 paragraph (1) number $4 \mathrm{a}$ and $4 \mathrm{~b}$ of the German Constitution (Grundgesetz).
} 
rights can be found in Spain. The Spanish Constitutional Court (Tribunal Constitucional de España) also has the power to examine constitutional complaint cases known as the recurso de amparo, which is an appeal for constitutional protection of fundamental rights against parliamentary decisions, governmental and administrative decisions, and judicial decisions. ${ }^{6}$

In Asia, it is imperative that the court in Asia actively participate in the Association of Asian Constitutional Courts and Equivalent Institutions (AACC), an Asian regional forum for constitutional justice which provides the opportunity for AACC member institutions to regularly exchange ideas and share their experiences of constitutional adjudication to promote the development of democracy, rule of law and fundamental rights in Asia. The AACC members have adopted a system of constitutional adjudication in a variety of models. Then, when it comes to jurisdictions, out of sixteen AACC members, there are four countries hold a power to examine constitutional complaint cases, ${ }^{7}$ such as Azerbaijan, ${ }^{8}$ South Korea, ${ }^{9}$ Thailand, ${ }^{10}$ and Turkey. ${ }^{11}$ In this context, a comparative perspective among AACC members state is expected to provide lessons for the other AACC members that do not have a constitutional complaint mechanism, particularly for Indonesia.

With constitutional complaint mechanism, the issue of fundamental rights, and the rights of citizens can be accommodated and carried out to a high level of competence by the constitutional court. But, of course, there must be limitations first of what can be deliberated or tried at the constitutional court. What matters can be considered under a constitutional complaint mechanism? These questions are discussed in detail based on the experiences and practises in several countries through a comparative perspective.

Therefore, this paper aims to explain the constitutional complaint mechanism from a comparative perspective: discussing models, procedure, and decision. The

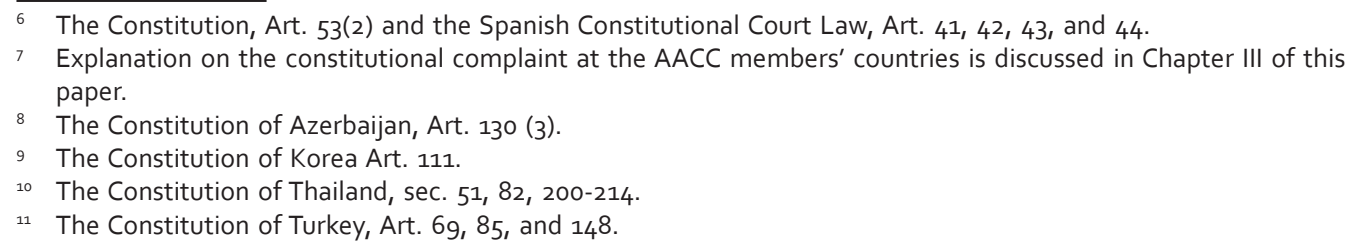


study is conducted through a theoretical inquiry concerning the constitutional complaint and comparing the constitutional complaint in three countries in Europe and four AACC member countries.

\section{EUROPEAN MODELS OF CONSTITUTIONAL COMPLAINT}

The constitutional complaint is one of the essential issues to be dealt with by many countries issues adopting the constitutional court. Each country has different circumstances and experiences regarding the practice of constitutional complaint, which are influenced by different legal systems, historical backgrounds, and the various different conditions that exist in each country. In Europe, there are three countries that have interesting models of constitutional complaints, such as Austria, Germany, and Spain.

In this part, the author attempt to summarize the constitutional complaint in Austria, Germany, and Spain that were the subject of a comparative study, and then provide some explanations of the differences among them. Therefore, the exchange of information and practical experience is necessary and brings significant benefits for the citizens and the protection of their constitutional rights in their respective countries.

\subsection{Austria}

Austria has been chosen as a reference since Hans Kelsen established the first Constitutional Court of Austria (Verfassungsgerichtshoft) in 1920, rejected the American model and adopted the European model of constitutional review. The United States adheres to the Anglo Saxon system and the institution who has functioned as the guardian of the constitution is the Supreme Court. So it is different from Austria which embraces the Continental European system. The Austrian model has a separate judicial institution outside the Supreme Court, which carries out the function of the constitutional review.

The organization and structure of the Austrian Constitutional Court consist of a president, a vice-president, 12 additional members and six substitute members, all of them appointed by the Federal President on the recommendation of the 
Federal Government, and these members and the substitute members shall be elected from among judges, administrative officials, and professors of law. The federal government of Austria has the right to recommend candidates for appointment as president, vice-president, six members, and three substitute members; three members and two substitute members are elected on the basis of proposals submitted by the National Council; another three members and one substitute member are proposed by the Federal Council. ${ }^{12}$

Regarding the jurisdictions, the Austrian Constitutional Court has jurisdictions to examine judicial review cases, ${ }^{13}$ review of regulations,${ }^{14}$ review of state treaties, ${ }^{15}$ review of rulings by the administrative tribunals, ${ }^{16}$ decisions in a conflict of jurisdiction arising under constitutional laws, ${ }^{17}$ establishment of jurisdiction (the Constitutional Court has to establish whether an intended act of legislation or enforcement is within the authority of the federal or provincial government), ${ }^{18}$ electoral jurisdiction, ${ }^{19}$ and jurisdiction over entities of the state..$^{20}$

\subsubsection{Models of the Constitutional Complaint}

The Austrian Constitutional Court refers to constitutional complaint as Individualantrag-Bescheidbeschwerde that can be given by any person who claims to be harmed directly in respect of one of their rights by regulation, a law, or an international treaty. ${ }^{21}$

The constitutional review of laws represents the core of constitutional court jurisdiction. Article 140 of the Austrian Constitution states that the Court pronounces furthermore whether laws are unconstitutional when an applicant claims a direct violation of personal rights through such unconstitutionality in

\footnotetext{
12 The Austrian Constitution (Bundes-Verfassungsgesetz (BVG)), Art. 147. See also "Brochure: the Constitutional Court of Austria," the Constitutional Court of Austria, 13, accessed August 22, 2018, https://www.vfgh.gv.at/ verfassungsgerichtshof/publikationen/information_material.en.html.

13 The Austrian Constitution (BVG), Art. 140.

4 The Austrian Constitution Art. 139.

The Austrian Constitution, Art. 140 .

The Austrian Constitution, Art. 144.

The Austrian Constitution, Art. 138 paragraph (1).

The Austrian Constitution, Art. 138 paragraph (2) and $148 f$.

The Austrian Constitution, Art. 141.

The Austrian Constitution, Art. 142 and 143.

${ }_{21}$ The Austrian Constitution, Art. 139, 140, and 140a and The Austrian Constitutional Court Statute (Verfassungsgerichtshofgesetz (VerfGG)), Art. 57.
} 
so far as the law has become useful for the applicant without the delivery of a judicial decision.

While the Constitutional Court jurisdiction to review international treaties stipulated in Article 140a of the Austrian Constitution, the Constitutional Court is not in a position to revoke a state treaty that has been found to be against the law; it can only establish its unconstitutionality or unlawfulness.

The Austrian Constitutional Court also has the vital authority of pronouncing on complaints against rulings by the administrative tribunals. In such a complaint, the appellant may claim either the violation of a constitutionally guaranteed right through the ruling or the violation of rights through the application of a general unlawful norm underlying the ruling, above all an unconstitutional law. The complaint can be filed after all other stages of legal remedy have been exhausted. ${ }^{22}$

Unlike at the Federal Constitutional Court of Germany, the constitutional complaint handled by the Austrian Constitutional Court is not allowed to challenge a court decision although the court's decision is alleged to violate fundamental rights.

\subsubsection{Admission Procedures}

The procedure for filing a constitutional complaint before the Austrian Constitutional Court is stipulated in the Articles 139 and 140 of the Constitution for the unconstitutionality of statutes and on the illegality of regulation, and Article 144 of the Austrian Constitution for direct individual complaints against an administrative decision.

In the case of a review of the lawfulness of regulations, Article 139 of the Constitution indicates that the Austrian Constitutional Court pronounces on the illegality of regulations. In order for the constitutional complaint to be admissible, Article 57 (1) of the Constitutional Court Act stipulated that if such request is filed by a person claiming direct infringement of his rights by the unlawfulness of the regulation it shall also state to what extent the person has

22 The BVG, Art. 144 and The VerfGG, Art. 82. 
been affected by such regulation without a court decision having been rendered or administrative decision having been issued.

In the case of examining the constitutionality of statutes (Article 140 of the Austrian Constitution), in order for the complaint to be admissible, Article 62 (1) of the Constitutional Court Act stated that the request to repeal a statute on the grounds of being unconstitutional shall claim that either the full contents of the statute or certain of its parts be repealed on the grounds of being unconstitutional. The request shall detail the objections put forward against the constitutionality of the law.

In the case of complaints about the against an administrative decision violating a person's rights through the application of an illegal general norm (Article 144 of the Austrian Constitution), the period for submitting a complaint against a decision is six weeks of its delivery. ${ }^{23}$ The applicant is requested shall contain, the classification of the disputed decision and the Administrative Court that declared it, the facts of the case, the statement whether the complainant claims that the disputed decision has infringed constitutionally guaranteed rights or violated his rights, a specific request, and the information required to decide whether the complaint has been filed in due time. ${ }^{24}$

\subsubsection{Decisions}

The Austrian Constitutional Court decisions are generally taken by the plenum of the Constitutional Court and this is constituted if the President and at least eight other justices are present, ${ }^{25}$ the decisions of the Constitutional Court shall be taken after a public oral hearing to which applicant, opponent, and any other involved parties shall be summoned. ${ }^{26}$

The Constitutional Court may revoke a law as unconstitutional only to the extent that its rescission was expressly asked or the Court would have to apply the law in the suit pending with it. ${ }^{27}$ The decision by the Constitutional Court

\footnotetext{
The VerfGG, Art. 82(1).

24 The VerfGG, Art. 82(4).

The VerfGG, Art. 7.

The VerfGG, Art. 19

The BVG, Art. 140(1).
} 
which revokes a law as unconstitutional imposes on the Federal Chancellor or the Governor the obligation to publish the rescission without delay. ${ }^{28}$

The circumstance is different if the complaint's subject-matter regards an international treaty. In this case, the Constitutional Court cannot revoke the treaty as unconstitutional but can only declare it non-applicable, and this decision binds all institutions which are required to execute that treaty. ${ }^{29}$

\subsection{Germany}

Germany as a reference was due to the fact that Germany is one of the countries who have the most advanced and established the constitutional court system, even though it is not the oldest. Since its founding in 1951, the Federal Constitutional Court has been playing a significant role in the securing of basic democratic order, the rule of law and fundamental rights protection, and through its decisions have strengthened the constitutional system in Germany.

The Federal Constitutional Court consist of two Senates and each Senate has eight justices..$^{30}$ Each Senate has its own authorities but always decides as "the Federal Constitutional Court." The First Senate is concerned predominantly with conflicts between the state and citizens, which the first Senate has authority to examine judicial review cases in which the main issue is the alleged incompatibility of a legal provision with fundamental rights or rights under Articles 33, 101, 103 and 104 of the Basic Law, and constitutional complaint cases with the exception of constitutional complaints pursuant to Article $91,^{31}$ as well as constitutional complaints concerning electoral law. ${ }^{32}$

Meanwhile, the Second Senate decides on conflicts between state organs, 33 which the second Senate is authorized to examine the forfeiture of constitutional

\footnotetext{
28 The BVG, Art. 140(5).

29 The BVG, Art. 140. See also Mario Patrono, "The Protection of Fundamental Rights by Constitutional Court Comparative Perspective," Victoria University of Wellington Law Review 31, no. 2, (May 2000): 417.

30 The Federal Constitutional Court, Art. 2 par. (1) and (2).

${ }_{31}$ The Act on the Federal Constitutional Court, Art. 91, regulates about municipalities may submit a constitutional complaint claiming that federal or Land law violates the provisions of Article 28 of the Basic Law.

32 The Act on the Federal Constitutional Court, Art. 14(1).

33 The Act on the Federal Constitutional Court, Art. 14(2).
} 
rights, ${ }^{34}$ the dissolution of the political party, ${ }^{35}$ complaints in proceedings involving the scrutiny of elections, ${ }^{36}$ impeachment of the Federal President, ${ }^{37}$ constitutional disputes between federal organs, ${ }^{38}$ review of statutes upon application by a constitutional organ, ${ }^{39}$ constitutional disputes between the Federation and the Laender, ${ }^{40}$ impeachment of federal and Land judges, ${ }^{41}$ Status of a provision of public international law as part of federal law, ${ }^{42}$ and disagreements on whether law continues to be valid as federal law, ${ }^{43}$ as well as for review proceedings and constitutional complaints not assigned to the First Senate.

\subsubsection{Models of the Constitutional Complaint}

The German Federal Constitutional Court refers to the constitutional complaint mechanism known as verfassungsbeschwerde. ${ }^{44}$ Everybody (not just specific public authorities) has an access to this jurisdiction, and the number of those who make use of this opportunity is much more significant than in other jurisdictions. ${ }^{45}$ Therefore, the Court has a high-level workload, which receives some 6.000 constitutional complaints per year. From 7 September 1951 to 31 December 2018, a total of 238.048 proceedings were brought before the Federal Constitutional Court. ${ }^{46}$

As underlined in article 93(1) of the Basic Law for the Federal Republic of Germany stated that a constitutional complaint might be lodged by an individual

\footnotetext{
34 The Basic Law for the Federal Republic of Germany, Art. 18.

35 The Basic Law for the Federal Republic of Germany, Art. 21(2).

${ }^{36}$ The Basic Law for the Federal Republic of Germany, Art. 41(2).

37 The Basic Law for the Federal Republic of Germany, Art. 61.

38 The Basic Law of Germany. Art. 93(1) number 1.

39 The Basic Law for the Federal Republic of Germany, Art. 93(1) number 2.

40 The Basic Law of Germany, Art. 93(1) number 3 and Article 84(4) second sentence.

${ }_{41}$ The Basic Law for the Federal Republic of Germany, Art. 98(2) and (5).

42 The Basic Law of Germany, Art. 100(2).

43 The Basic Law for the Federal Republic of Germany, Art. 126.

44 The Federal Constitutional Court's authority to decide constitutional complaints cases stated in Art. 93 (1) number $4 a$ and $4 b$ of the Basic Law for the Federal Republic of Germany and Art. 90 to 95 of the Act on the Federal Constitutional Court.

45 Caroline Elisabeth Wittig, "Ideological Values and their Impact on the Voting Behavior of Justices of the Federal Constitutional Court of Germany" (Thesis Master of Public Administration, Bowling Green State University, August 2009), 27.

${ }_{46}$ German Federal Constitutional Court, "Annual Statistic 2018," published on February 2019, accessed on 22 February 2019, https://www.bundesverfassungsgericht.de/SharedDocs/Downloads/EN/Statistik/statistics_2018. pdf?_blob=publicationFile \&v=4.
} 
citizen claiming that one of his or her rights has been violated by the public authority (law, administrative act, or court decision).

The reason submitted in the constitutional complaint must explain the constitutional right which has been violated, and the act or omission of the organ or authority by which the complainant claims his or her rights have been violated. ${ }^{47}$ In detail as stipulated in the Federal Constitution, it is stated that a constitutional complaint can be made if any of the following rights are violated by the public authority, particularly the fundamental right contained in Article 20 (Basic principles of state order, Right of resistance), Article 33 (Equal citizenship - Public service), Article 38 (election), Article 101 (Ban on extraordinary courts), Article 103 (Fair trial), and Article 104 (Deprivation of liberty)..$^{8}$

\subsubsection{Admission Procedures}

The application for constitutional complaint shall be submitted to the Federal Constitutional Court in writing, it must state reasons, and the necessary evidence must be listed. ${ }^{49}$ As determined by Article 93(1) No. 4a of the Basic Law, the constitutional complaint, which may be filed "by any person" alleging that one of his fundamental rights has been infringed "by public authority..$^{\circ}$

The article above means several things. First, the phrase of "any person" means every physical person or legal person, including foreigners. Second, the phrase "public authority" means all acts which are committed by a Federal or State authority which violates to the fundamental rights, such as the constitutional complaint against the law, administrative act, or court decision.

The time limit of constitutional complaints application regulated in Article 93 of the Act on the Federal Constitutional Court. The constitutional complaint against the court and administrative decisions must be lodged within one month to be admissible, and the complete reasoning of the complaint must also be

47 The Act on the Federal Constitutional Court, Art. 92.

48 The Basic Law of Germany, Art. 93(1) No. 4a.

49 The Act on the Federal Constitutional Court, Art. 23.

50 The Basic Law of Germany, Art. 93(1) No. 4a. 
submitted within this period..$^{51}$ If applicants were unable to apply with this time limit through no mistake of their own, they shall, upon application, be granted reinstatement into their previous procedural position. The application shall be submitted within two weeks of the removal of the cause for their non-compliance. Reasons for the request shall be stated either in the application itself or during the proceedings and their factual basis substantiated by prima facie evidence. Fault on the part of the applicant's authorized representative shall be deemed equal to fault on the part of the complainant. ${ }^{52}$ The constitutional complaint examines a law or another sovereign act against which legal recourse is not possible, the complaint may only be lodged within one year of the law entering into force or of the sovereign act being issued. 53

\subsubsection{Decisions}

The Constitutional Court shall decide in secret deliberations at its discretion and based on the opinion resulting from the hearing and the evidence obtained. The decision shall be set in writing, shall provide reasons and shall be signed by the participating Justices. ${ }^{54}$ However, the pronouncements of the decisions shall be public.55 If a Justice expressed a different view on the decision or its argumentation during the deliberations, he or she might set forth this viewpoint in a separate opinion; the separate opinion shall be attached to the decision. The Senates may publish the distribution of votes in their decisions. ${ }^{66}$ The nature of the decision is final and binding upon the constitutional organs of the Federation and the Laender, as well as on all courts and those with public authority. ${ }^{57}$

\footnotetext{
${ }_{51}$ Art. 93(1) first sentence of the Act on the Federal Constitutional Court. See also German Federal Constitutional Court, "How to Lodge the Constitutional Complaint." Last Modified March 2018, 2. Accessed August 22, 2018, https://www.bundesverfassungsgericht.de/EN/Homepage/_zielgruppeneinstieg/Merkblatt/Merkblatt_node.html.

${ }_{52}$ The Act on the Federal Constitutional Court, Art. 93(2). See also German Federal Constitutional Court, "How to Lodge the Constitutional Complaint," 2.

53 The Act on the Federal Constitutional Court, Art. 93(3).

54 The Act on the Federal Constitutional Court, Art. 30 (1).

55 The Act on the Federal Constitutional Court, Art. 17 a.

${ }^{56}$ The Act on the Federal Constitutional Court, Art. 30(2).

57 The Act on the Federal Constitutional Court, Art. 31(1).
} 


\subsection{Spain}

The Spanish Constitutional Court was created in 1978 whose operational setting was done by the Organic Law No. 2/1979 on the Constitutional Court. Spain has been chosen because the Spanish Constitutional Court jurisdictions is comparatively broad and its covers the whole Spanish territory.

The organizational structure of the Spanish Constitutional Court shall consist of twelve members selected by the King. Of these, four members shall be nominated by the Congress (parliament) by a majority of three-fifths of its members, then four shall be nominated by the Senate with the same majority, two shall be appointed by the Spanish Government, and two by the General Council of the Judicial Power..$^{8}$ The term of office of Constitutional Court justice shall be nine years, one-third of the Constitutional Court being renewed every three years. ${ }^{59}$

The Spanish Constitutional Court has jurisdiction to rule on the implementation of the constitutional review of laws, acts, and regulations; constitutional complaint (recurso de amparo) against violation of the rights and freedoms; disputes of the jurisdiction between the State and the Self-governing Communities or between the Self-governing Communities themselves; disputes between the constitutional bodies of the State; conflicts in defence of local selfgovernment; and declaration concerning the constitutionality of international treaties. ${ }^{60}$

\subsubsection{Models of the Constitutional Complaint}

One of the Spanish Constitutional Court main powers is a constitutional complaint or appeal is the so-called recurso de amparo, this jurisdiction has the function to guarantee of fundamental rights and freedoms derived from the constitution. As determined by Article 53(2) of the Spanish Constitution, any citizen may assert a claim to protect the liberties and fundamental rights recognised in the Articles 14 to 30 of the Spanish Constitution, have been

$5^{8}$ The Spanish Constitution, Art. 159(1).

59 The Spanish Constitution, Art. 159(3).

6o The Spanish Constitution, Art. 161 and The Constitutional Court Law, Art. 2. 
violated by a Spanish public authority ${ }^{61}$ by lodging an individual appeal for protection (recurso de amparo) to the Constitutional Court.

Individual appeals for protection (recurso de amparo) against violation of the rights and freedoms, more specifically, recurso de amparo can be exercised to challenge legal enactments, omissions unconstitutional actions (vía de hecho) by the public authorities, the Autonomous Communities and other territorial, corporate or public institutional, as well as by their officials. ${ }^{62}$ Furthermore, the amparo appeal shall be available against violations of the judicial decisions. ${ }^{63}$

The Constitutional Court of Spain Act distinguishes three types of amparo depending on the origin of the act of public authority which allegedly constitutes a violation of fundamental rights, appeal against parliamentary decision, ${ }^{64}$ appeal against governmental and administrative decisions, ${ }^{65}$ and appeal against judicial decision. ${ }^{66}$ Moreover, the Organic Law on the Electoral System provides two types of amparo against acts and decisions of the electoral administration, appeal against the agreements of the Electoral Boards on proclamation of candidates and candidates, ${ }^{67}$ and appeal against the agreements of the Electoral Boards on proclamation of elected and election and proclamation of Presidents of Local Corporations. ${ }^{68}$

\subsubsection{Admission Procedures}

The application for recurso de amparo shall be submitted directly to the Spanish Constitutional Court, according to Article 162(1) (b) of the Spanish constitution states that, any person or body corporate with a legitimate interest, as well as the Defender of the People and the Public Prosecutor's Office are entitled to lodge an appeal. Before filing the appeal against governmental or

\footnotetext{
61 The Spanish Constitution, Art. 14 to 30 , regulate the protection of fundamental rights and freedom such as equality before the law and public liberties.

62 The Act of the Constitutional Court of Spain, Art. 41(2).

${ }_{63}$ In cases in which a court decision is questioned, Art. 47(1) of the Act of the Constitutional Court of Spain states that those profited by the decision, act or fact that affected to the appeal or individual with a legitimate interest therein may appear in the proceedings for protection as a defendant.

${ }_{64}$ The Act of the Constitutional Court of Spain, Art. 42.

65 The Act of the Constitutional Court of Spain, Art. 43.

66 The Act of the Constitutional Court of Spain, Art. 44.

${ }_{67}$ The Act of the Electoral System of Spain, Art. 49(3).

68 The Act of the Electoral System of Spain, Art. 114(2).
} 
administrative decisions or against judicial decisions, the applicant must show to have exhausted any remedies available before ordinary courts.

The standing to lodge the amparo appeal, Article 46 of the Act of the Constitutional Court of Spain states that, in the case of appeal against parliamentary decision, the person directly concerned, the Ombudsperson and the Public Prosecutor Office. While, in the case of against governmental and administrative decisions, as well as appeal against judicial decision, the parties to the corresponding judicial proceedings, the Ombudsperson and the Public Prosecutor Office.

The deadlines for filing the complaint against governmental or administrative decisions shall be twenty days from the date of announcement of the ruling given in the previous legal proceedings. ${ }^{69}$ Furthermore, the deadline for lodging an amparo appeal against judicial decisions shall be thirty days from the date of announcement of the ruling given in the judicial proceedings. ${ }^{70}$

\subsubsection{Decisions}

The Spanish Constitutional Court decision is final, or no appeal may be brought against them, when the court declares the unconstitutionality of an act or a statute with the force of an act and all those which are not limited to the acknowledgment of an individual right, shall be fully binding on all persons and it has effect erga omnes. ${ }^{11}$

The decision delivered of the appeal may grant or deny the requested amparo. According to Article 53 of the Spanish Constitutional Court Act, the Chamber, or where appropriate the Section, having examined the case on its merits, shall deliver one of the following judgments: a) granting of protection (otorgamiento de amparo); and b) denial of protection (denegación de amparo)..$^{72}$

69 The Act of the Constitutional Court of Spain, Art. 43(2). See also "Amparo (Appeal for Constitutional Protection of Fundamental Rights)," The Constitutional Court of Spain, accessed August 22, 2018, https://www. tribunalconstitucional.es/en/tribunal/Composicion-Organizacion/competencias/Paginas/04-Recurso-de-amparo. aspx.

70 The Act of the Constitutional Court of Spain, Art. 44(2). See also the Constitutional Court of Spain, "Amparo (Appeal for Constitutional Protection of Fundamental Rights)."

71 The Spanish Constitution, Art. 164 (1).

72 The Act of the Constitutional Court of Spain, Art. 53. 
Furthermore, when the judgment will be granting of protection, it should contain any of the following, a) declaration of invalidity of the Court decision, act or questioned resolution; b) public perception of the right or freedom violated; c) restoration of the appellant in the integrity of his or her rights or freedom by adopting appropriate measures, and where appropriate, for its conservation. ${ }^{73}$

\section{MODELS OF CONSTITUTIONAL COMPLAINT IN AACC MEMBERS}

The primary purpose of this paper is to explain the model of constitutional complaint in the AACC members. The general description of AACC members will be discussed in the first sections. In the second section, the author will specifically discuss the constitutional complaint in AACC members to obtain a comprehensive picture regarding the models, procedures and decisions.

\subsection{General Description of AACC Members}

Before discussion about the jurisdictions, this paper will mention briefly about the idea of establishing the AACC. Discussion about the idea of establishing the AACC began in 2005 at the 3rd Conference of Asian Constitutional Court Judges in Mongolia. Several countries agreed with the establishment of the AACC, then followed up with signing the Memorandum of Understanding on the Preparatory Committee for the establishment of the AACC at the 5th Conference of Asian Constitutional Court Judges held in Seoul, Korea in October 2007.74 Finally, in Jakarta, July 2010, the AACC was officially launched and it was agreed to convene the Inaugural Congress in Korea..$^{75}$ The purpose of establishing the AACC is to promote the development of democracy, rule of law and fundamental rights in Asia.

The AACC has sixteen members, which are institutions of constitutional justice respectively from Afghanistan, Azerbaijan, Indonesia, Kazakhstan, Korea, Kyrgyz Republic, Malaysia, Mongolia, Myanmar, Pakistan, The Philippines, Russia,

\footnotetext{
73 The Act of the Constitutional Court of Spain, Art. 55.

74 MoU Signatories: Indonesia, Korea, Mongolia and the Philippines.

75 Adopted the Jakarta Declaration on the Establishment of the AACC.
} 
Tajikistan, Thailand, Turkey, and Uzbekistan. In carrying out its functions, the AACC has three permanent secretariats which have different functions. First, the Constitutional Court of Indonesia hosts the Secretariat for Planning and Coordination; second, the Constitutional Court of Korea hosts the Secretariat for Research and Development; and third, the Constitutional Court of Turkey runs a Center for Training and Human Resources Development.

The sixteen AACC members have a variety of organizational structures, jurisdictions, and procedures, which are influenced by different legal systems, historical backgrounds, and the various conditions that exist in each member. It reflects the diversity of fundamental rights protection systems. It is generally accepted that the system of constitutional adjudication in today's world can be classified into two types, each reflecting different historical backgrounds. The decentralized type is the American model of judicial review in which the power to review the constitutionality of state action is distributed throughout the regular courts. The centralized type is the European model in which the power to decide constitutional issues is concentrated in a particular independent agency that is separate from the ordinary courts. ${ }^{76}$

The AACC members that implement the American model system in which the institution that has a role as the guardian of the constitution is the Supreme Court, consist of Malaysia, Pakistan, and Philippine. While the AACC members that apply the Austrian model, which has a separate judicial institution outside the Supreme Court, consist of Afghanistan, Azerbaijan, Indonesia, Kyrgyzstan, Kazakhstan, Korea, Mongolia, Myanmar, Russia, Tajikistan, Thailand, Turkey, and Uzbekistan.

However, when it comes to jurisdictions, out of sixteen AACC members, only four AACC members have the authority to handle the constitutional complaint mechanism in their jurisdictions, namely Azerbaijan, Korea, Turkey, and Thailand.

76 The Constitutional Court of Korea, Thirty Years of the Constitutional Court of Korea (Seoul: The Constitutional Court, 2018), 66. 


\subsection{Constitutional Complaint in Four AACC Member}

As discussed above that out of the sixteen AACC members there are four countries that have constitutional complaint jurisdiction, namely Azerbaijan, Korea, Turkey, and Thailand. In this part, The Author attempt to summarize the constitutional complaint at AACC Members that were the subject of a comparative study, and then provide some explanations of the differences among them.

\subsubsection{Azerbaijan}

The Constitutional Court of Azerbaijan was established on 14 July 1998, which functions to guarantee the supremacy of the Constitution of Azerbaijan and to protect fundamental rights and freedoms of each person. In carrying out these powers, the Constitutional Court shall be based on the principle of supremacy of the Constitution of the Azerbaijan Republic as well as principles of independence, collegiality, and publicity. ${ }^{77}$

According to Article 130 of the Constitution of Azerbaijan that regulates the jurisdictions of the Constitutional Court, the Constitutional Court adopts decisions on the correspondence of laws, decrees and other normative legal acts to the Constitution and laws. Furthermore, the Constitutional Court also gives an interpretation of the Constitution and laws.

One of the main powers of the Constitutional Court of Azerbaijan is constitutional complaint. Article 34(1) of the Law on the Constitutional Court of Azerbaijan states that any individual who alleges that his or her fundamental rights have been violated by the normative legal act of the Legislative and Executive, or an act of the municipality and courts, may submit a complaint to the Constitutional Court in order to restore his/her fundamental rights and freedoms.

The Constitutional Court can examine individual complaints against judicial decisions in the following cases: if the normative legal act which should have been applied was not applied by a court; if a normative legal act which should

77 The Law on the Constitutional Court of Azerbaijan, Art. 4. 
not have been applied was applied by a court; and if normative legal act was not properly interpreted by a court. $7^{8}$

\subsubsection{Application Procedures}

The application for constitutional complaint shall be submitted to the Constitutional Court of Azerbaijan in accordance with the procedure stipulated in the Law on the Constitutional Court of Azerbaijan. The reasons for the complaint must be proven within the complaint, where the rights and freedoms of the complainant had been violated by legislative acts in force, normative acts of executive power, the acts adopted by a municipality or a court. There are also some technical requirements, such as identity, deadlines, complaint form, stamp duty, the language, as well as the title and date of the disputed act and other necessary matters. ${ }^{79}$

The constitutional complaint can be submitted to the Constitutional Court after exhaustion of all remedies. The time limit for the complaint to be submitted to the Constitutional Court is within six months from the moment of the entrance into force of the decision of the court of the last instance, ${ }^{80}$ or within three months from the date of violation of the complainant's right to apply to Constitutional Court. ${ }^{81}$

Regarding the legal standing, according to Article 34(1) of the Constitutional Court Law, "any person" who alleges that his/her rights and freedoms have been violated by the normative legal act of the Legislative and Executive, the acts adopted by a municipality or a court may submit a complaint to the Constitutional Court.

While, according to Article 32(2) of the Constitutional Court Law, the Ombudsman of the Azerbaijan Republic shall apply to the Constitutional Court in cases where the rights and freedoms of a person had been violated by legislative acts in force, normative acts of executive power, the acts adopted by a municipality or a court. It means, the procedure of constitutional complaint

78 The Law on Constitutional Court of Azerbaijan, Art. 34.1.

79 The Law on the Constitutional Court of Azerbaijan, Art. 34.6.

so The Law on the Constitutional Court of Azerbaijan, Art. 34.4.1.

81 The Law on the Constitutional Court of Azerbaijan, Art. 34.4.2. 
to the Constitutional Court is indirect, since the first step for the applicant is to complain to the Ombudsman.

Regarding the procedure of examination, constitutional complaint cases shall be delivered to the session of the Panel of the Constitutional Court within 30 days, and there shall be affirmed a ruling as to admissibility or rejection of complaint. If the complaint is inadmissible, the complaint shall be sent to the applicant within seven days after its adoption. Otherwise, if the complaint is declared admissible, the examination on the merits of a complaint by the Constitutional Court shall start within 60 days after admission for examination. ${ }^{82}$

\subsubsection{Decisions}

After all trial sessions have been completed, Justices will decide whether the complaint is granted or not. The Constitutional Court decisions are final and binding. There are three types of final judgment on the request for adjudication. First, the complaint will be rejected if the complaint is irrational and unfounded. Second, the complaint will be dismissed if the complaint was made unlawfully. Third, the complaint will be granted if five or more Justices deem the request to have the reason(s) and is justified. ${ }^{83}$

\subsubsection{South Korea}

The Korean Constitutional Court has just celebrated its thirtieth anniversary, since its establishment thirty years ago in 1988, the Constitutional Court of Korea has been playing a significant role in protecting of fundamental rights and constitutional values through an impartial interpretation of the constitution, and the Court decisions also have strengthened the constitutional system in Korea.

In terms of the organizational structure, the Constitutional Court of Korea shall be composed of nine Justices qualified to be court judge, and they shall be appointed by the President. ${ }^{84}$ Among the Justices, three shall be appointed from persons selected by the National Assembly, and three shall be elected from

\footnotetext{
82 The Law on the Constitutional Court of Azerbaijan, Art. 52 (1), (2), and (3).

83 The Constitutional Court of Azerbaijan, "AACC Member Fact File: Constitutional Court of Azerbaijan," in The Jurisdictions and Organization of AACC members, ed. AACC SRD (Seoul: AACC SRD, 2018), 40.

${ }^{84}$ The Korean Constitution, Art. 111(2).
} 
person nominated by the Chief Justice of the Supreme Court. ${ }^{85}$ The president of the Court shall be appointed by the President of the Republic of Korea from among the Justices with the approval of the National Assembly. ${ }^{86}$

The jurisdiction of the Court are stipulated in Article 111(1) of the Korean Constitution, and the Constitutional Court shall have the jurisdictions of constitutional review, ${ }^{87}$ impeachment, dissolution of a political party, resolving competence disputes, and adjudicating constitutional complaint. Because of all these powers, the Constitutional Court occupies a very strategic and influential position, and the Court is said to be the guardian of the constitution.

Constitutional complaint at the Constitutional Court of Korea is an essential jurisdiction in the efforts to guarantee the protection of fundamental rights of the citizen as guaranteed by the Korean Constitution. There are two types of constitutional complaints available in Korea. First, based on Article 68(1) of the Constitutional Court Act, any person who claims that his or her fundamental rights have been violated by an exercise or omission of state power, excluding the judgments of the ordinary courts, can file a constitutional complaint. ${ }^{88}$ Second, another type of constitutional complaint is mentioned in Article 68(2) of the Constitutional Court Act, if a motion made under Article 41(1) of the Constitutional Court Act for request of adjudication on constitutionality of laws is denied by the ordinary court, the party may file a constitutional complaint to the Constitutional Court.

The two kinds of the complaint are distinct, Article 68(1) can be used in situations where existing laws do not afford remedies through ordinary court processes for unconstitutional state action. It should be noticed that the decisions of ordinary courts are not eligible for the petition. ${ }^{89}$ Article $68(2)$ prescribes

85 The Korean Constitution, Art. 111(3).

86 The Korean Constitution, Art. 111(4).

87 The Korean Constitutional Court does not have the competence of abstract review.

88 Art. 68(1) The Constitutional Court Act: "Any person whose basic rights guaranteed by the Constitution is infringed due to exercise or non-exercise of the governmental power, excluding judgment of the ordinary courts, may file a constitutional complaint with the Constitutional Court: Provided, That if any remedy is provided by other laws, no one may file the constitutional complaint without having exhausted all such processes".

89 Dae-Kyu Yoon, "The Constitutional Court System of Korea: The New Road for Constitutional Adjudication," Journal of Korean Law 1, no. 2, (2001): 11. 
a special form of constitutional complaint, which is tied to the procedure of "norm-control" in the process of constitutional review of legislation. This is one of the institutional factors that enabled early stabilization of the constitutional adjudication system in Korea and which facilitated public recognition of constitutional review as the last resort in protecting individuals' fundamental rights. $9^{\circ}$

\subsubsection{Application Procedures}

The application for constitutional complaint under Article 68(1) requires that the applicant shall include the information of the complainant and his or her counsel, infringed rights, exercise or omission of state power by which the infringement of the right is caused, bases for the request and other necessary matters. ${ }^{91}$ While the issues to be stated on the application for complaint under Article 68(2) is actually the same with adjudication on the constitutionality of statutes as regulated in Article 43, when an ordinary court requests a complaint to the Constitutional Court, the court's written request shall include the information of the requesting ordinary court, information of the case and the parties, the statute or any provision which is interpreted as unconstitutional, based on which a statute is interpreted as unconstitutional, and other necessary matters. ${ }^{92}$

The time limit for filing a constitutional complaint under Article 68(1) shall be filed within 90 days after the occurrence of the cause is known, and within one year after the cause happens. If a constitutional complaint is filed after exhausting remedial processes provided by other laws, it shall be filed within 30 days after the final decision in these processes has been made. ${ }^{93}$ While a complaint under Article 68(2) shall be filed within 30 days after a denial of a motion to request for review on the constitutionality of the statute is notified. ${ }^{94}$

\footnotetext{
go Kang-Kook Lee, "The Past, and Future of Constitutional Adjudication in Korea, in Current Issues in Korean Law," ed. Laurent Mayali and John Yoo (California: Robbins Collection Publication School of Law University of California at Berkeley, 2014), 3.

91 The Korean Constitutional Court Act, Art. 71(1).

92 The Korean Constitutional Court Act, Art. 43.

93 The Korean Constitutional Court Act, Art. 69(1).

94 The Korean Constitutional Court Act, Art. 69(2).
} 
Furthermore, the procedure of examination, according to Article 72 of the Constitutional Court Act that regulates about prior review states that the President of the Court may set the Panels each of which consists of three Justices and have the Panels take a prior review of a constitutional complaint. 95 The Panel shall dismiss a constitutional complaint unanimously as a result of the non-satisfaction of formal requirements for constitutional complaint..$^{6}$

\subsubsection{Decisions}

The decision of the constitutional complaint cases shall bind all the state agencies and the local governments. ${ }^{97}$ In upholding a constitutional complaint under Article 68(1), the violated fundamental rights and the exercise or nonexercise of governmental power by which the infringement has been caused shall be specified in the holding of the decision of upholding..$^{8}$ In the case related to in paragraph (2), the Constitutional Court may revoke the exercise of governmental power which infringes fundamental rights or confirms that the non-exercise thereof is unconstitutional. ${ }^{9}$

There are three types of final judgment on the request for adjudication. First, rejection means the request is irrational and unfounded. Second, dismissal means that the request was made unlawfully. Third, upholding means six or more Justices deem the request to have reason(s) and is justified. ${ }^{100}$

\subsubsection{Turkey}

The Turkish Constitutional Court was created by the constitution drafted after the military coup on May 27, 1960. The 1961 Constitution created the Turkish Constitutional Court to establish a constitutional review of legal action by the legislature. ${ }^{101}$ In that period, only a few countries in Europe (Austria, Germany, and Italy) had a constitutional adjudication system. Therefore, the Turkish

95 The Korean Constitutional Court Act, Art. 72(1).

96 The Korean Constitutional Court Act, Art. 72(2).

97 The Korean Constitutional Court Act, Art. 75(1).

98 The Korean Constitutional Court Act, Art. 75(2).

99 The Korean Constitutional Court Act, Art. 75(3).

100 Constitutional Court of Korea, "AACC Member Fact File: Constitutional Court of Korea," in The Jurisdictions and Organization of AACC members, ed. AACC SRD (Seoul: AACC SRD, 2018), 117.

${ }_{101}$ Cenap Cakmak and Cengiz Dinc, "Constitutional Court: Its Limits to Shape Turkish Politics," Insight Turkey 12, no. 4, (2010): 7 . 
Constitutional Court is one of the oldest Constitutional Court established in Europe. ${ }^{102}$ Turkey is a member of the Council of Europe, as well as a member of the AACC.

The composition, powers, and organizational structure of the Constitutional Court were changed considerably by the constitutional amendments in 2010, and a new law was enacted in 2011. The composition of the Constitutional Court is based on the representation model. The Constitutional Court of Turkey shall be composed of fifteen members. ${ }^{103}$ The Constitutional Court members shall be chosen for a term of twelve years and non-renewable, and they shall retire when they are over the age of sixty-five. ${ }^{104}$

The jurisdiction of the Turkish Constitutional Court is regulated in Article 69 and 148 of the Turkish Constitution, the Constitutional Court maintained its powers to exercise abstract and concrete norm review, ${ }^{105}$ individual application (constitutional complaint), adjudicate on the dissolution of political parties, carry out the financial audit of political parties, and trial of statesmen before the Supreme Criminal Court. ${ }^{106}$

The individual application was introduced into the Turkish legal system by the 2010 constitutional amendments, ${ }^{107}$ and 23 September 2012 was determined as the first day of receiving applications. ${ }^{108}$ According to Article 148 paragraph 3 of the Turkish Constitution "everyone may apply to the Constitutional Court because one of the fundamental rights within the scope of the ECHR which are guaranteed by the constitution has been infringed by state power. To make an application ordinary legal remedies must be exhausted."

\footnotetext{
102 "Introductory Booklet of the Constitutional Court of Turkey," Constitutional Court of Turkey, 9, accessed August 22, 2018, https://www.anayasa.gov.tr/en/publications/introductory-booklet/.

103 The Turkish Constitution (As amended on January 21, 2017, ; Act No. 6771), Art. 146.

104 The Turkish Constitution, Art. 147.

${ }_{105}$ The Constitutional Court shall examine the constitutionality, in respect of both form and substance of laws, presidential decrees and the Rules of Procedure of the Grand National Assembly of Turkey

106 The explanation of the last jurisdiction is the Constitutional Court, acting as the Supreme Criminal Court, tries for offences relating to their official functions the President, Vice President or Ministers, and other high-level state officials.

107 The Individual application was introduced in Turkish Constitutional Court with the provisions in provisional article 18 and Articles 148 and 149 of 1982 Constitution amended with Law no. 5982 adopted the constitutional referendum on 12/9/2010.

${ }_{108}$ Constitutional Court of Turkey, "Introductory Booklet of the Constitutional Court of Turkey," 23.
} 
The individual application can be lodged by those who claim to suffer, as a result of action of public authorities, a violation of any of their fundamental rights and freedoms as guaranteed in the Turkish Constitution, which simultaneously are secured under the European Convention on Human Rights (ECHR) and its additional Protocols ratified by Turkey. ${ }^{109}$ As a member of the Council of Europe, Turkey is bound to the ECHR.

\subsubsection{Application Procedures}

The individual application must be lodged with an application form by those, whose fundamental rights which are guaranteed by the Turkish Constitution and are simultaneously within the scope of the ECHR and the additional protocols thereto, are directly alleged to have been violated due to the act or action that is challenged. ${ }^{110}$

According to Article 45(1) of the Turkish Constitutional Court Act, "everyone" can lodge an individual application to the Constitutional Court. However, foreigners are not eligible to file an individual application concerning the rights that are only granted to Turkish citizens. The public legal person cannot make an individual application, but legal persons of private law (associations, foundations, commercial partnerships, etc.) can do so, making an individual application with the justification that only the rights of the legal person as they are have been violated."'

An individual application should be filed within thirty days starting from the exhaustion of legal remedies. An applicant who fails to apply within the due duration upon just excuse can apply in fifteen days starting from the ending date of such excuse and with evidence bearing proof of their reasons. The Constitutional Court shall accept or reject such request first by way of examination of the admissibility of the applicant's excuse. ${ }^{122}$

\footnotetext{
${ }^{109}$ Huseyin Ekinci and Musa Saglam, Individual Application to the Turkish Constitutional Court (Ankara: The Constitutional Court of Turkey, 2015), 5 .

110 Before lodging an individual application, all legal and administrative remedies must be exhausted.

111 The Turkish Constitutional Court Act, Art. 46(2).

112 The Turkish Constitutional Court Act, Art. 47(5).
} 
In the process of examination of the admissibility of individual application, the admissibility review shall be made by Commissions. Concerning claims that have been concluded unanimously to fail to fulfill the criteria for admissibility, a decision of inadmissibility shall be taken, and decisions of inadmissibility are final. ${ }^{13}$ Then, for the examination on merits, the merits of the application shall be reviewed by Sections. During the investigation, commissions and sections can carry out all sorts of research and examination regarding whether or not a fundamental right has been violated. ${ }^{114}$

\subsubsection{Decisions}

After all steps examinations have been carried out, the Turkish Constitutional Court will decide whether the right of the applicant has been violated or not. In individual application cases, applications may be found inadmissible at any stage for failure to satisfy formal requirements. Applications that fail to meet the admissibility requirements (non-exhaustion of remedies, rules about competence etc) are concluded with inadmissibility decision without any further examination. If admissible, it means that an application meets requirements so that the applications will be examined on the merits.

Examination on whether or not there is a violation of the fundamental right in the subject incident of the application is made during the investigation on the merits by Sections. This decision establishes whether or not there is a violation of fundamental right and what should be done to redress it if a violation is established."15 The effect of the judgment is limited to the concerned individual(s). The Court cannot strike down legislation or other secondary norms through individual application mechanism. ${ }^{16}$

\subsubsection{Thailand}

The Constitutional Court of Thailand was introduced by the 2007 Constitution after a military coup d' état in 2006 against then Prime Minister Thaksin. ${ }^{117}$ The

\footnotetext{
113 The Turkish Constitutional Court Act, Art. 48.

${ }_{114}$ The Turkish Constitutional Court Act, Art. 49.

115 Huseyin Ekinci and Musa Saglam, Individual Application to the Turkish Constitutional Court, 104.

${ }_{116}$ Constitutional Court of Turkey, "AACC Member Fact File: Constitutional Court of Turkey," in The Jurisdictions and Organization of AACC members, ed. AACC SRD (Seoul: AACC SRD, 2018), 288-289.

${ }_{117}$ Glaser, Henning, "Thai Constitutional Courts and the Political Order," Seoul Law Journal 53, no. 2, (June 2012 ): 65.
} 
2007 Constitution redesigned the Constitutional Court to be more politically isolated and powerful. ${ }^{118}$

Regarding the organizational structure, the Constitutional Court of Thailand has nine judges, which consist of three career judges from the Supreme Court, two judges from the Supreme Administrative Court, one qualified person in law, one qualified person in political science or public administration, and two qualified persons obtained by selection from persons holding or having held a position not lower than Director-General or a position equivalent to a head of government agency, or a position not lower than Deputy Attorney-General. ${ }^{19}$

Furthermore, according to Section 210 of the Constitution of Thailand stipulates,

the Constitutional Court has duties and powers as follows: (1) to adjudicate on the constitutional review of law or bill; (2) to consider and adjudicate on a question regarding duties and powers of the House of Representative, the Senate, the National Assembly, the Council of Ministers or Independent Organs; (3) other duties and powers prescribed in the Constitution.

Other duties and powers of the Constitutional Court of Thailand is to protect people's rights and liberties or can be categorized as a constitutional complaint. First, adjudication on an application of the people or community against a state agency under Chapter V of the Constitution of Thailand (Duties of the State). In this jurisdiction, the Court must ensure that the state does not violate the people or community right. ${ }^{120}$

Second, the Constitutional Court of Thailand can adjudicate on an application of the people whose rights or liberties according to the Constitution are violated as stipulated in Section 213 of the Constitution of Thailand:

an individual whose rights guaranteed by the constitution are violated, has the right to submit a complaint to the Constitutional Court for a decision on whether such an act is contrary to or inconsistent with the Constitution,

\footnotetext{
118 Kemthong Tonsakulrungruang, "Development in Thai Constitutional Court," In 2016 Global Review of Constitutional Law, ed. Richard Albert, David Landau, Pietro Faraguna, and Simon Drugda (I.CONnect and the Clough Center for the Study of Constitutional Democracy at Boston College, 2017), 211, http://www.iconnectblog.com/2017/08/ now-available-the-i\%C2\%B7connect-clough-center-2016-global-review-of-constitutional-law/.

119 The Constitution of Thailand, sec. 200.

${ }_{120}$ The provisions of the duties of the state stipulated in Section $54^{-60}$ of the Constitution of Thailand.
} 
according to the rules, procedures, and conditions prescribed by the Organic Act on Procedures of the Constitutional Court.

\subsubsection{Application Procedures}

There are two differences of constitutional complaint procedures under Chapter V and Section 213 of the Constitution of Thailand. First, the procedure of adjudication on an application of the people or community against a state agency under Chapter V is as follows: if the people or community suffers any damage from an omission of act, malfunction, or delay of act of a government official, they have the right to file an application to the Constitutional Court according to Section 45 of the Organic Act on the Procedure of the Constitutional Court B.E. 2561 (2018). To be more specific, they follow up and urge a state agency to perform such act, but the agency refuses or keeps silent for 90 days, and also they lodge their complaint to the Ombudsman. In this case, if the Ombudsman is of the opinion that the state agency performs its functions relevant to the duties of the state, the Ombudsman shall notify the complainant. However, if the Ombudsman is not of that opinion, he shall notify the Council of Ministers. Then, after considering the Ombudsman's views, the Council of Ministers shall make an order and notify the people and community. Nonetheless, unless the people or community agrees with such order regarding the duties of the state according to Chapter V, they shall have the right to apply to the Constitutional Court. ${ }^{121}$

Second, the other procedure of adjudication on an application of the people whose rights or liberties according to the Constitution are violated is stipulated in Section 213 of the Constitution of Thailand. The issue here concerns a situation where people's rights or freedom according to the Constitution are directly infringed by the act of government agencies, government officials, or other agencies which exercise state powers, and such violation causes any damage or is troublesome to the said people. Individuals have the right to complain to the Ombudsman within 90 days. After receiving such complaint,

${ }_{121}$ Sumaporn Srimoung and Pitaksin Sivaroot, "The Organisation and Jurisdiction of the Constitutional Court of the Kingdom of Thailand," (Paper Presented at the AACC Research Conference, Mei 2018), 13-14. 
the Ombudsman shall consider and file an application to the Constitutional Court within 6o days and notify the complainant within ten days. In the case where the Ombudsman is of opinion to cease his consideration and investigation, or he does not inform the complainant within 60 days since the date of the recipient, such people have the right to file his or her application or complaint (individual complaint) to the Court for a decision on whether such an act is contrary with the Constitution. ${ }^{122}$

\subsubsection{Decisions}

Section 211 of the Constitution of Thailand prescribed the following essential rules on the constitutional court decision and effect, which states

a decision of the Constitutional Court shall be made by a majority of votes unless otherwise prescribed by the Constitution." Furthermore, "The decision of the Constitutional Court shall be final and binding on the National Assembly, the Council of Ministers, Courts, Independent Organs, and State agencies." ${ }^{23}$

\section{A COMPARISON ON CONSTITUTIONAL COMPLAINT AND A NECESSITY FOR INDONESIA}

Comparative study on constitutional complaint from several countries in Europe such as Austria, Germany, and Spain as well as from four AACC member countries, showing similarities and differences that can be seen from their forms and procedures, including objects, standing, and time limits.

However, this variety of systems for constitutional complaint, particularly in Austria, Germany, and Spain shows on the effectiveness of the protection of fundamental rights. The details of the differences of constitutional complaints will be explained in the following table:

\footnotetext{
${ }_{122}$ Sumaporn Srimoung and Pitaksin Sivaroot, "The Organisation and Jurisdiction of the Constitutional Court of the Kingdom of Thailand," 14 .

123 The Constitution of Thailand, sec. 211.
} 


\section{Table 1}

Constitutional Complaint in Europe

\begin{tabular}{|c|c|c|c|}
\hline \multirow{2}{*}{ Country } & \multicolumn{3}{|c|}{ Constitutional Complaint } \\
\hline & Object & Standing & Time Limits \\
\hline Austria & $\begin{array}{l}\text { A complaint against } \\
\text { laws, regulations, } \\
\text { international } \\
\text { treaties, and against } \\
\text { administrative actions }\end{array}$ & $\begin{array}{l}\text { Any person who } \\
\text { claims to be } \\
\text { harmed directly in } \\
\text { regard to one of } \\
\text { their rights }\end{array}$ & Six weeks \\
\hline Germany & $\begin{array}{l}\text { A complaint against an } \\
\text { act of public authority: } \\
\text { constitutionality of } \\
\text { the law; } \\
\text { - administrative act; } \\
\text { and } \\
\text { - court decision }\end{array}$ & $\begin{array}{l}\text { Any individual } \\
\text { alleging that one } \\
\text { of his fundamental } \\
\text { rights has been } \\
\text { infringed by public } \\
\text { authority }\end{array}$ & One month \\
\hline Spain & $\begin{array}{l}\text { A complaint against } \\
\text { parliamentary } \\
\text { decisions, governmental } \\
\text { and administrative } \\
\text { decisions, and judicial } \\
\text { decisions }\end{array}$ & $\begin{array}{l}\text { Any individual or } \\
\text { body corporate, } \\
\text { as well as the } \\
\text { Defender of the } \\
\text { People and the } \\
\text { Public Prosecutor's } \\
\text { Office }\end{array}$ & $\begin{array}{l}30 \text { days (amparo } \\
\text { against judicial } \\
\text { decisions). } \\
\text { 20 days } \\
\text { (appeal against } \\
\text { governmental or } \\
\text { administrative } \\
\text { decisions) }\end{array}$ \\
\hline
\end{tabular}

According to the models of constitutional complaint in Europe as mentioned in the table above, Germany and Spain permit constitutional complaints against any act of public authority, including statutes and court decisions, while Austria provides this remedy only against acts of Parliament, regulations, international treaties, and administrative actions.

Standing provisions for constitutional complaint are the same in three jurisdictions under consideration Austria, Germany and Spain, claiming suffering a personal and direct violation of constitutional rights by the public authority as a requirement for resorting to the Constitutional Court. Taking into account the substantive scope of constitutional rights, a complainant may be individual 
or body corporate, as well as citizen foreigner. ${ }^{124}$ These three countries also provide direct access to the Constitutional Court.

Whereas the AACC members as mentioned in the previous chapter, explained that out of sixteen AACC members there are four members have the constitutional complaint mechanism in their jurisdiction, the four countries are Azerbaijan, Korea, Turkey, and Thailand. The comparative analysis of the constitutional complaint among four AACC members will be explained in the following table:

\section{Table 2}

Constitutional Complaint in Four AACC Members

\begin{tabular}{|c|c|c|c|}
\hline \multirow{2}{*}{$\begin{array}{c}4 \text { AACC } \\
\text { Members }\end{array}$} & \multicolumn{3}{|c|}{ Constitutional Complaint } \\
\hline & Object & Standing & $\begin{array}{l}\text { Time } \\
\text { Limits }\end{array}$ \\
\hline Azerbaijan & $\begin{array}{l}\text { The complaint against the } \\
\text { normative legal act of the } \\
\text { Legislative and Executive, } \\
\text { act of municipality and } \\
\text { courts }\end{array}$ & $\begin{array}{l}\text { Any person who } \\
\text { alleges that his/ } \\
\text { her rights have been } \\
\text { infringed }\end{array}$ & Six months \\
\hline $\begin{array}{l}\text { South } \\
\text { Korea }\end{array}$ & $\begin{array}{l}\text { The complaint against an } \\
\text { exercise or omission of } \\
\text { state power (Art. 68(1)) } \\
\text { The complaint against } \\
\text { a court's denial of a } \\
\text { request for constitutional } \\
\text { review of a statute in any } \\
\text { judicial proceeding (Art. } \\
68(2) \text { ). }\end{array}$ & $\begin{array}{l}\text { Any person who } \\
\text { claims that his/her } \\
\text { rights have been } \\
\text { violated }(68(1)) \\
\text { The party whose } \\
\text { its request on } \\
\text { constitutionality of } \\
\text { statutes is rejected } \\
(68(2))\end{array}$ & \begin{tabular}{|l} 
- \\
(Art. days \\
(Art. \\
68(1)) \\
3o days \\
(Art. \\
$68(2))$
\end{tabular} \\
\hline Turkey & $\begin{array}{l}\text { Individual application } \\
\text { concerning fundamental } \\
\text { rights under the joint } \\
\text { protection of the } \\
\text { Constitution and ECHR. }\end{array}$ & $\begin{array}{l}\text { Everyone can file an } \\
\text { individual application, } \\
\text { but foreigners are not } \\
\text { eligible to do so for } \\
\text { rights that are only } \\
\text { granted to Turkish } \\
\text { citizens. }\end{array}$ & 30 days \\
\hline
\end{tabular}

124 Nino Tsereteli, "Mechanism of Individual Complaints - Germany, Spanish and Hungarian Constitutional Court Comparative Analysis" (LL.M Thesis, Central European University, Hungary, 2 April 2007), 11. 


\begin{tabular}{l|l|l|l}
\hline Thailand & $\begin{array}{l}\text { The complaint against a } \\
\text { state agency (duties of } \\
\text { the state) } \\
\begin{array}{l}\text { The complaint against } \\
\text { people's rights or } \\
\text { liberties violations. }\end{array}\end{array}$ & $\begin{array}{l}\text { People or } \\
\text { community } \\
\text { A person whose } \\
\text { rights or liberties } \\
\text { are violated }\end{array}$ & 90 days
\end{tabular}

The four AACC member countries mentioned above show that the constitutional complaint jurisdiction represents an essential mechanism for individuals who suffered from violations of fundamental rights guaranteed by the constitution. Therefore, the substantial part of the constitutional court workload in these countries is taken up by constitutional complaint. There are similarities and differences in the models and characteristics of constitutional complaint. In Azerbaijan, the Constitutional Court can handle constitutional complaint against the normative legal act of the legislative and executive, an act of a municipality and courts. Compared to Azerbaijan, constitutional complaint in South Korea and Thailand slightly more restricted, since even though constitutional complaints against an exercise and non-exercise of state powers are allowed, and constitutional complaints against court decisions are prohibited. In Turkey, one finds a very specific type of constitutional complaint, which is directly connected to a regional human rights protection system. The Turkish Constitutional Court handles complaints from individuals concerning violations of human rights and freedoms falling under the joint protection of the Constitution and the ECHR.

In terms of standing, constitutional complaint functions in the same way in three countries (Azerbaijan, South Korea, and Thailand), where everyone can file a constitutional complaint (excluding foreigners). Especially in Thailand, not only can individuals but also groups (the people or community) can also have legal standing to file constitutional complaint in the context of the non-performance of duties by a state agency. In Turkey, everyone can file an individual application to the Constitutional Court, but foreigners are explicitly not allowed to file an individual application concerning the rights that are 
only granted to Turkish citizens. It means that in Turkey a foreigner also has legal standing to file constitutional complaints, but is strictly limitated to the context of specific rights.

Concerning the access to the constitutional complaint mechanism, the four countries have differences, the following figures will explain which country applies direct and indirect access to the Constitutional Court.

\section{Figure 1}

Direct Access to the Constitutional Court
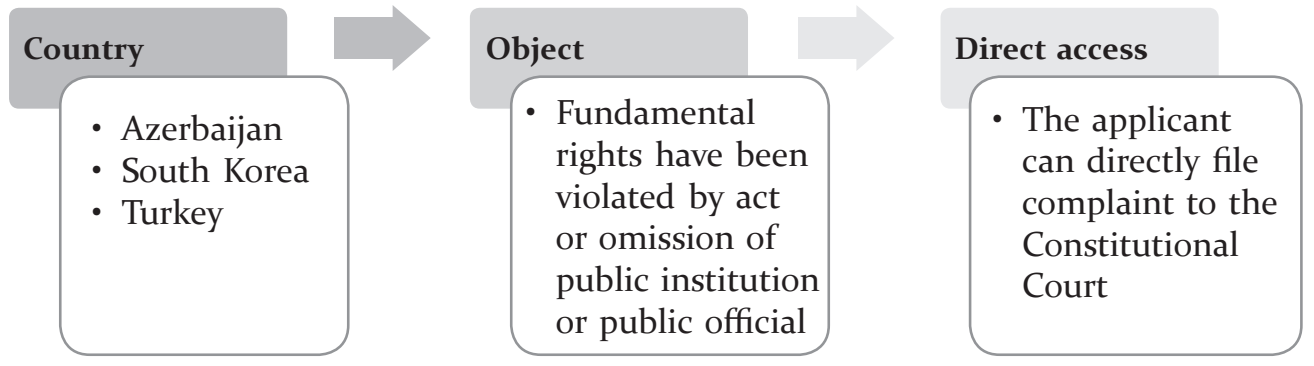

According to the figure above, there are three countries, Azerbaijan, South Korea, and Turkey, which provide the citizen with direct access to file a constitutional complaint to the Constitutional Court. This direct mechanism is an effort to increase the effectiveness of protecting fundamental rights, enabling individuals to quickly obtain legal certainty over the problems they face.

\section{Figure 2}

\section{Indirect Access to the Constitutional Court}

\begin{tabular}{|c|c|c|c|}
\hline Country & Object & Indirect access & Complaint to the Court \\
\hline - Thailand & $\begin{array}{l}\text { The people's or } \\
\text { community's } \\
\text { rights have been } \\
\text { violated by a } \\
\text { state agency } \\
\text { - Individual } \\
\text { whose rights } \\
\text { guaranteed by } \\
\text { the constitution } \\
\text { are violated }\end{array}$ & $\begin{array}{l}\text { - The applicant } \\
\text { should } \\
\text { first file a } \\
\text { complaint } \\
\text { to the } \\
\text { Ombudsman }\end{array}$ & $\begin{array}{l}\text { - If the applicant } \\
\text { disagrees with the } \\
\text { Ombudsman's } \\
\text { decision, then } \\
\text { the applicant has } \\
\text { the right to file } \\
\text { the individual } \\
\text { complain to the } \\
\text { Court }\end{array}$ \\
\hline
\end{tabular}


While in Thailand, the procedure of constitutional complaint to the Constitutional Court of Thailand is indirect, since the first step for the applicant is to complain to the Ombudsman within 90 days. Then, the Ombudsman shall consider and file an application to the Constitutional Court within 6o days. If the Ombudsman is of the opinion to cease his consideration and investigation, or he does not inform the complainant within 6o days since the date of receiving the application, then the applicant has the right to file the individual complaint to the Constitutional Court.

A comparative perspective on the relevant AACC members as mentioned above can yield lessons for other AACC members which do not have a constitutional complaint mechanism. This is particularly so for AACC members who are or have been considering the introduction of constitutional complaint, such as Indonesia.

In Indonesia, each of the alternative methods to adopt constitutional complaint certainly has its own deficiencies and advantages. The first alternative is amending again the constitution which is requires a complicated process, besides requiring a long time. Second, via legislative action, the legislative amends the existing law or even establishes a new law concerning the Constitutional Court. However, such legislative interpretation could be challenged again by the people, so this approach may not provide an easily settled course of action. Third, the introduction of constitutional complaint via constitutional interpretation by the Constitutional Court may also be possible, but such an approach can only be used as long as there is a concrete case that involves the connection with some norm of law.

Each alternative has its imperfections, but the possible way to adopt constitutional complaint in Indonesia is while waiting for the People's Consultative Assembly (MPR) to amend the Constitution, the Constitutional Court can make a constitutional interpretation that constitutional complaint becomes part of the constitutional review system. Therefore, in the future, if the Indonesian Constitutional Court introduces constitutional complaint, it is 
estimated that this will lead to a very large number of cases. In this context, the Constitutional Court must increase the supporting system of the Justices, which includes researchers and substitute registrars. In addition, the Indonesian Constitutional Court also must make an effective and efficient procedural law as well as provide a suitable information technology (IT) system.

\section{CONCLUSION}

The constitutional complaint is one of the legal mechanisms designed to reinforce the guarantee of the protection of citizens' rights against any state action, in all branches of power that violates the rights of citizens. The constitutional court in many countries have adopted a constitutional complaint system in a variety of models. However, the first application of the constitutional complaint came from Europe. In Austria, the constitutional complaint is allowed against the administrative actions but not against the court decisions. While Germany and Spain have a similar model that is a complaint against an act of the public authority including court decisions.

In Asia, it is imperative that the court in Asia actively participate in the AACC, an Asian regional forum for constitutional justice which provides the opportunity for AACC members to regularly exchange ideas and share their experiences of constitutional adjudication to promote the development of democracy, rule of law and fundamental rights in Asia. When it comes to the AACC members jurisdiction, out of sixteen members, there are four members which have the authority to handle the constitutional complaint cases in their jurisdiction, namely Azerbaijan, Korea, Turkey, and Thailand. These also take a variety of different forms and models.

In Azerbaijan, constitutional complaint is comparatively broad. Azerbaijan's Constitutional Court can handle constitutional complaint against the normative legal act of the legislative and executive, an act of a municipality and the decisions of courts. In contrast, even though constitutional complaint in South Korea and Thailand can be against the exercise and non-exercise of state power, constitutional complaint cannot be filed against court decisions. In Turkey the 
constitutional complaint mechanism is coupled with the regional system of human rights protection. The Turkish Constitutional Court handles complaints from individuals concerning violations of human rights and freedoms falling under the joint protection of the Turkish Constitution and the ECHR.

A comparative perspective on the relevant AACC members can yield lessons for other AACC members which do not have a constitutional complaint mechanism. This is particularly so for AACC members who are or have been considering the introduction of constitutional complaint, such as Indonesia.

In Indonesia, each of the alternative methods to adopt constitutional complaint certainly has its own deficiencies and advantages. However, the possible way to adopt constitutional complaint in Indonesia is while waiting for the People's Consultative Assembly (MPR) to amend the Constitution, the Indonesian Constitutional Court can make a constitutional interpretation that constitutional complaint becomes part of the constitutional review system.

\section{BIBLIOGRAPHY}

Cakmak, Cenap and Cengiz Dinc. "Constitutional Court: Its Limits to Shape Turkish Politics." Insight Turkey 12, no. 4 (2010): 69-92.

Constitutional Court of Korea. Thirty Years of the Constitutional Court of Korea. Seoul: The Constitutional Court of Korea, 2018.

Constitutional Court of Korea. "AACC Member Fact File: Constitutional Court of Korea." In The Jurisdictions and Organization of AACC members, edited by AACC SRD, 107-135. Seoul: AACC SRD, 2018.

Constitutional Court of Austria. "Brochure: the Constitutional Court of Austria." Accessed August 22, 2018. https://www.vfgh.gv.at/verfassungsgerichtshof/ publikationen/information_material.en.html.

Constitutional Court of Turkey. "Introductory Booklet of the Constitutional Court of Turkey." Accessed August 22, 2018. https://www.anayasa.gov.tr/ en/publications/introductory-booklet/. 
Constitutional Court of Spain. "Amparo (Appeal Constitutional Protection of Fundamental Rights).” Accessed August 22, 2018. https://www. tribunalconstitucional.es/en/tribunal/Composicion-Organizacion/ competencias/Paginas/o4-Recurso-de-amparo.aspx.

Constitutional Court of Azerbaijan. "AACC Member Fact File: Constitutional Court of Azerbaijan." In The Jurisdictions and Organization of AACC members, edited by AACC SRD, 32-53. Seoul: AACC SRD, 2018.

Constitutional Court of Turkey. "AACC Member Fact File: Constitutional Court of Turkey." In The Jurisdictions and Organization of AACC members, edited by AACC SRD, 208-301. Seoul: AACC SRD, 2018.

Dannemann, Gerhard. "Constitutional Complaints: The European Perspective." The International and Comparative Law Quarterly 43, no. 1 (January 1994): 142-153.

Ekinci, Huseyin and Musa Saglam. Individual Application to the Turkish Constitutional Court. Ankara: The Constitutional Court of Turkey, 2015.

German Federal Constitutional Court. "How to Lodge the Constitutional Complaint." Last Modified March 2018. Accessed August 22, 2018. https:// www.bundesverfassungsgericht.de/EN/Homepage/_zielgruppeneinstieg/ Merkblatt/Merkblatt_node.html.

German Federal Constitutional Court. “Annual Statistic 2018," Published on February 2019. Accessed February, 22, 2019. https://www. bundesverfassungsgericht.de/SharedDocs/Downloads/EN/Statistik/ statistics_2018.pdf?_blob=publicationFile\&v=4.

Glaser, Henning. "Thai Constitutional Courts and the Political Order," Seoul Law Journal 53, no. 2 (June 2012): 65-163.

Lee, Kang-Kook, "The Past and Future of Constitutional Adjudication in Korea." In Current Issues in Korean Law, edited by Laurent Mayali and John Yoo, 1-13. California: Robbins Collection Publication School of Law University of California at Berkeley, 2014. 
Palguna, I Dewa Gede. "Constitutional Complaint and the Protection of Citizens the Constitutional Rights." Constitutional Review 3, no. 1, (May 2017): 1-23.

Patrono, Mario. "The Protection of Fundamental Rights by Constitutional Court - Comparative Perspective," Victoria University of Wellington Law Review 31, no. 2, (May 2000): 410-426.

Srimoung, Sumaporn and Pitaksin Sivaroot. "The Organisation and Jurisdiction of the Constitutional Court of the Kingdom of Thailand." Paper Presented at the AACC Research Conference, Mei 2018.

Tonsakulrungruang, Kemthong. "Development in Thai Constitutional Court." In 2016 Global Review of Constitutional Law, edited by Richard Albert, David Landau, Pietro Faraguna, and Simon Drugda, 211-215. I.CONnect and the Clough Center for the Study of Constitutional Democracy at Boston College, 2017. http://www.iconnectblog.com/2017/o8/now-available-thei\% 2 \%B7connect-clough-center-2016-global-review-of-constitutional-law/.

Tsereteli, Nino. "Mechanism of Individual Complaints - Germany, Spanish and Hungarian Constitutional Court - Comparative Analysis." LL.M Thesis, Central European University, Hungary, 2 April 2007.

Wittig, Caroline Elisabeth. "Ideological Values and their Impact on the Voting Behavior of Justices of the Federal Constitutional Court of Germany." Thesis Master of Public Administration, Bowling Green State University, August 2009.

Yoon, Dae-Kyu. "The Constitutional Court System of Korea: The New Road for Constitutional Adjudication." Journal of Korean Law 1, no. 2, (2001): 1-16. 